\title{
Dactylosporangium maewongense sp. nov., isolated from soil
}

\author{
Suthamat Chiaraphongphon, ${ }^{1}$ Chanwit Suriyachadkun, ${ }^{2}$ \\ Tomohiko Tamura ${ }^{3}$ and Chitti Thawai ${ }^{1}$
}

Correspondence

Chitti Thawai

ktchitti@kmitl.ac.th

\author{
'Department of Applied Biology, Faculty of Science, King Mongkut's Institute of Technology \\ Ladkrabang, Bangkok 10520, Thailand \\ ${ }^{2}$ BIOTEC Culture Collection, BIOTEC Central Research Unit, National Center for Genetic \\ Engineering and Biotechnology, National Science and Technology Development Agency, 113 \\ Thailand Science Park, Phaholyothin Road, Klong 1, Klong Luang, Pathumthani 12120, Thailand \\ ${ }^{3}$ Biological Resource Center, National Institute of Technology and Evaluation, 2-5-8 \\ Kazusakamatari, Kisarazu, Chiba, 292-0812, Japan
}

\begin{abstract}
Morphological and chemotaxonomic characterization of actinomycete strain $\mathrm{MW} 2-25^{\top}$, isolated from tropical forest soil in Nakhon Sawan Province, Thailand, clearly demonstrated that this strain belongs to the genus Dactylosporangium. Phylogenetic analysis using 16S rRNA gene sequences also indicated that this strain should be classified in the genus Dactylosporangium and showed that the closest relative was Dactylosporangium aurantiacum IFO $12592^{\top}(99.3 \%$ sequence similarity). DNA-DNA hybridization values and some physiological and biochemical properties indicated that this strain could be readily distinguished from its closest phylogenetic relatives. On the basis of these phenotypic and genotypic data, this strain represents a novel species, for which the name Dactylosporangium maewongense sp. nov. is proposed. The type strain is MW2-25 $5^{\top}\left(=\mathrm{BCC} 34832^{\top}=\mathrm{JCM} 15933^{\top}\right)$.
\end{abstract}

The genus Dactylosporangium Thiemann et al. (1967) belongs to the family Micromonosporaceae in the order Actinomycetales (Stackebrandt et al., 1997). This genus is well established and based on morphological characteristics (i.e. formation of finger-shaped sporangia directly on substrate hyphae) and 16S rRNA gene sequence-based phylogenetic analyses (Koch et al., 1996). At the time of writing, the genus Dactylosporangium encompasses six species with validly published names: Dactylosporangium aurantiacum (Thiemann et al., 1967), Dactylosporangium fulvum (Shomura et al., 1986), Dactylosporangium matsuzakiense (Shomura et al., 1980), Dactylosporangium roseum (Shomura et al., 1985), Dactylosporangium thailandense (Thiemann et al., 1967; Thiemann, 1970) and Dactylosporangium vinaceum (Shomura et al., 1983). Members of this genus can be distinguished from one another using morphological and biochemical properties and $16 \mathrm{~S}$ rRNA gene sequence analysis.

Abbreviation: $\mathrm{A}_{2} \mathrm{pm}$, diaminopimelic acid.

The GenBank/EMBL/DDBJ accession number for the $16 \mathrm{~S}$ rRNA gene sequence of strain MW2-25 $5^{\top}$ is AB495209.

Supplementary tables showing the cellular fatty acid composition of strain MW2-25 ${ }^{\top}$ and DNA-DNA relatedness values with the type strains of recognized species of the genus Dactylosporangium are available with the online version of this paper.
During an investigation of new actinomycetes from tropical forest soil from Thailand, we isolated strain $M W 2-25^{\mathrm{T}}$, which showed typical morphological and chemotaxonomic characteristics of the genus Dactylosporangium but was genotypically and phenotypically distinct from recognized species of the genus. Here, we describe the polyphasic characterization of the new strain and propose a novel species of the genus Dactylosporangium.

Strain MW2 $-25^{\mathrm{T}}$ was isolated from a soil sample collected from Maewong National Park in Nakhon Sawan Province, Thailand. The sample was taken from the soil surface and kept at $4{ }^{\circ} \mathrm{C}$. The sample was air-dried at room temperature for 8 days. Dried soil $(1 \mathrm{~g})$ was treated with $1.5 \%(\mathrm{v} / \mathrm{v})$ phenol in distilled water $(9 \mathrm{ml})$ and then serially diluted in sterile distilled water as recommended by Hayakawa et al. (1991). This organism was isolated on humic acid-vitamin (HV) agar, supplemented with $\left(1^{-1}\right)$ $25 \mathrm{mg}$ nalidixic acid, $50 \mathrm{mg}$ cycloheximide and $1 \mathrm{mg}$ terbinafin. A pure culture was preserved by freezing at $-80{ }^{\circ} \mathrm{C}$ and freeze-drying.

The morphological properties of strain $\mathrm{MW} 2-25^{\mathrm{T}}$ were observed after growth on modified soil extract agar, containing $0.5 \mathrm{~g} \mathrm{CaSO}_{4} .2 \mathrm{H}_{2} \mathrm{O}, 0.25 \mathrm{~g} \mathrm{Ca}\left(\mathrm{NO}_{3}\right)_{2} .4 \mathrm{H}_{2} \mathrm{O}$, $0.05 \mathrm{~g} \mathrm{MgSO}_{4} .7 \mathrm{H}_{2} \mathrm{O}, 0.03 \mathrm{~g} \mathrm{~K}_{2} \mathrm{SO}_{4}, 0.02 \mathrm{~g} \mathrm{KH}_{2} \mathrm{PO}_{4}, 0.1 \mathrm{~g}$ $\mathrm{NaHCO}_{3}, 0.02 \mathrm{~g} \mathrm{CaCl}_{2} .2 \mathrm{H}_{2} \mathrm{O}, 0.1 \mathrm{~g}$ yeast extract, $0.1 \mathrm{~g}$ Casamino acids, $0.2 \mathrm{~g}$ glucose, $100 \mathrm{ml}$ soil extract (Hamaki 
et al., 2005), $18 \mathrm{~g}$ agar and $900 \mathrm{ml}$ distilled water ( $\mathrm{pH} 7.0$ ), by light and scanning electron microscopy (JSM 5410 LV; JEOL). The sample for scanning electron microscopy was prepared as described by Itoh et al. (1989).

Phenotypic characteristics were examined by using several standard methods. Cultural characteristics were tested using 14 day cultures grown at $30{ }^{\circ} \mathrm{C}$ on various agar media. The Jacal Colour Card L2200 (Japan Colour Research Institute) was used for determining colour designations. The hydrolysis of various compounds was examined using the basal medium recommended by Gordon et al. (1974). The temperature, $\mathrm{pH}$ and $\mathrm{NaCl}$ tolerances were determined on yeast extract-malt extract agar (International Streptomyces Project, ISP 2 medium; Shirling \& Gottlieb, 1966). Carbon source utilization was tested by using ISP 9 medium (Shirling \& Gottlieb, 1966) supplemented with a final concentration of $1 \%$ of the carbon source and $0.05 \%$ Casamino acids. Gelatin liquefaction, milk peptonization, nitrate reduction and starch hydrolysis were determined through cultivation on various media as described by Arai (1975) and Williams \& Cross (1971). Melanin and hydrogen sulfide production were examined on slants of tyrosine agar and peptone iron agar supplemented with $0.1 \%(\mathrm{w} / \mathrm{v})$ yeast extract.

Freeze-dried cells used for chemotaxonomic analyses were obtained from cultures grown in ISP 2 broth on a rotary shaker at $30{ }^{\circ} \mathrm{C}$ for 4 days. Cell-wall peptidoglycan was prepared and hydrolysed by the methods of Kawamoto et al. (1981) and the amino acid composition was analysed by TLC (Lechevalier \& Lechevalier, 1980). The isomer of diaminopimelic acid $\left(\mathrm{A}_{2} \mathrm{pm}\right)$ in the cell wall was determined by the method of Staneck \& Roberts (1974). The acyl group of muramic acid in the peptidoglycan was determined by the method of Uchida \& Aida (1984). The reducing sugars from whole-cell hydrolysates were analysed by the cellulose TLC method of Komagata \& Suzuki (1987). Phospholipids in cells were extracted and analysed using the method of Minnikin et al. (1984). Fatty acid methyl ester analysis was performed by GLC according to the instructions of the Microbial Identification System (MIDI) (Sasser, 1990; Kämpfer \& Kroppenstedt, 1996). The presence of mycolic acids was investigated according to the method of Minnikin et al. (1975). Isoprenoid quinones were extracted by the method of Collins et al. (1977) and were analysed by HPLC equipped with a Cosmosil $5 \mathrm{C}_{18}$ column $(4.6 \times 50 \mathrm{~mm}$; Nacalai Tesque $)$. The elution solvent was a mixture of methanol and 2-propanol $(2: 1, \mathrm{v} / \mathrm{v})$.

Chromosomal DNA was isolated from cells grown in ISP 2 broth according to the method of Tamaoka (1994). The $\mathrm{G}+\mathrm{C}$ content of the DNA was determined using the HPLC method of Tamaoka \& Komagata (1984) using an equimolar mixture of nucleotides (Yamasa Shoyu) as the quantitative standard. DNA-DNA hybridization was conducted in microdilution-well plates as reported by Ezaki et al. (1989). DNA-DNA relatedness was deter- mined by using the colorimetric method (Verlander, 1992). PCR-mediated amplification of the 16S rRNA gene and sequencing of the PCR products were carried out as described previously (Suriyachadkun et al., 2009). The $16 \mathrm{~S}$ rRNA gene sequence was aligned with selected sequences obtained from the GenBank/EMBL/DDBJ databases by using CLUSTAL w version 1.81 (Thompson et al., 1994). The alignment was manually verified and adjusted prior to the construction of a phylogenetic tree. The phylogenetic tree was constructed by using the neighbour-joining (Saitou \& Nei, 1987) and maximum-parsimony (Kluge \& Farris, 1969) methods in MEGA version 2.1 (Kumar et al., 2001). The confidence values of branches of the phylogenetic tree were determined using bootstrap analyses (Felsenstein, 1985) based on 1000 resamplings. The values for sequence similarity among the closest strains were determined using the EzTaxon server (Chun et al., 2007).

It was apparent from both morphological and chemical properties that strain MW2 $-25^{\mathrm{T}}$ is a member of the genus Dactylosporangium (Thiemann et al., 1967; Shomura et al., 1983). Colonies of strain MW2 $-25^{\mathrm{T}}$ were compact and raised and produced well-developed branched substrate hyphae, but lacked aerial hyphae. Growth of the novel strain was good on yeast extract-malt extract agar (ISP 2), inorganic salts-starch agar (ISP 4) and glycerol-asparagine agar. The colour of the colonies was yellowish orange to strong yellowish orange. No soluble pigment was produced in these media. The novel strain formed finger-shaped sporangia on short sporangiophores that emerged directly from substrate hyphae (Fig. 1a). The sporangium surface
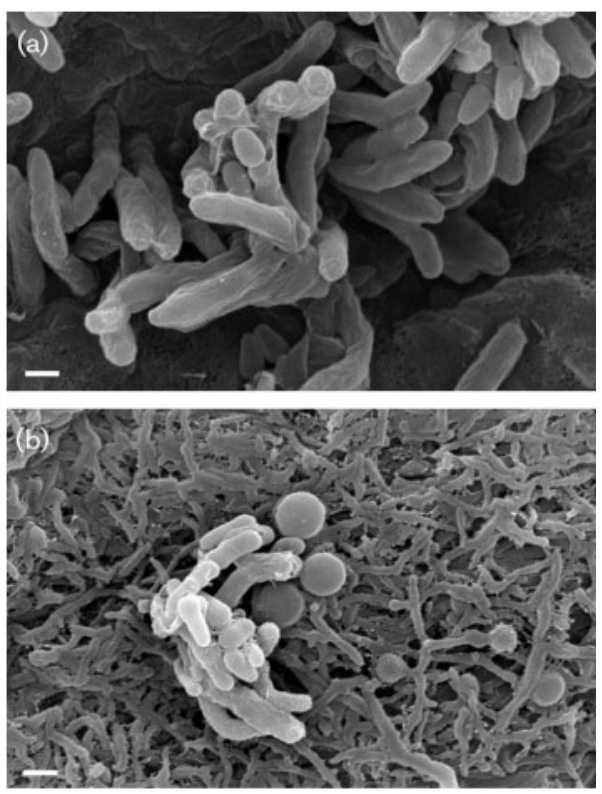

Fig. 1. Scanning electron micrographs of sporangia (a) and globose bodies (b) of strain MW2-25 ${ }^{\top}$ grown on humic acidvitamin agar for 4 weeks at $28^{\circ} \mathrm{C}$. Bars, $1 \mu \mathrm{m}$. 
was irregular rugose. Each sporangium contained a row of ovoid motile spores $(0.9-1.1 \mu \mathrm{m})$. Globose bodies were observed on modified soil extract agar and HV agar (Fig. 1b). The cell-wall hydrolysates contained glutamic acid, glycine, alanine, meso- $\mathrm{A}_{2} \mathrm{pm}$ and 3-hydroxy-meso- $\mathrm{A}_{2} \mathrm{pm}$, indicating that this strain has cell-wall chemotype II of Lechevalier \& Lechevalier (1970). The acyl type of the cellwall muramic acid was glycolyl. Glucose, xylose, rhamnose, ribose and trace amounts of arabinose were found as whole-cell sugars (whole-cell sugar pattern D of Lechevalier \& Lechevalier, 1970). Characteristic phospholipids were diphosphatidylglycerol, phosphatidylglycerol, lysyl phosphatidylglycerol and phosphatidylethanolamine, but not phosphatidylcholine. This pattern corresponds to phospholipid type PII of Lechevalier et al. (1977). The fatty acid pattern of strain MW2-25 $5^{\mathrm{T}}$ consists of iso- $\mathrm{C}_{16: 0}(27.9 \%)$, iso- $\mathrm{C}_{15: 0} \quad(25.9 \%)$, anteiso- $\mathrm{C}_{15: 0}(15.4 \%)$, iso- $\mathrm{C}_{14: 0}$ $(7.9 \%)$, anteiso- $\mathrm{C}_{17: 0}(7.3 \%)$, iso- $\mathrm{C}_{17: 0}(2.3 \%), \mathrm{C}_{18: 0}$ (2.3\%), $\mathrm{C}_{16: 0}(2.2 \%), \mathrm{C}_{17: 0}(2.2 \%)$, cis-9-C $\mathrm{C}_{18: 1}(2.0 \%)$, anteiso- $\mathrm{C}_{17: 1}(1.1 \%)$, cis-9- $\mathrm{C}_{17: 1}(0.8 \%)$ and 10-methyl$\mathrm{C}_{17: 0}(0.8 \%)$ (see Supplementary Table S1, available in IJSEM Online). This pattern corresponds to fatty acid type $3 \mathrm{~b}$ of Kroppenstedt (1985). Mycolic acids were absent. The predominant menaquinones were MK-9 $\left(\mathrm{H}_{8}\right)(43.7 \%)$ and MK-9 $\left(\mathrm{H}_{6}\right)(37.4 \%)$. The $\mathrm{G}+\mathrm{C}$ content of the DNA was $73.2 \mathrm{~mol} \%$.
An almost-complete 16S rRNA gene sequence (1468 nt) was obtained for strain MW2-25 $5^{\mathrm{T}}$. This sequence exhibited a close relationship with members of the family Micromonosporaceae and strain MW2 $-25^{\mathrm{T}}$ was placed within the clade of the genus Dactylosporangium. It is evident from Fig. 2 that strain MW2 $-25^{\mathrm{T}}$ formed a subclade with $D$. aurantiacum IFO $12592^{\mathrm{T}}$ with a high bootstrap value ( $99 \%$ in the neighbour-joining tree). The relationship between these strains was supported by the results from the maximum-parsimony method. 16S rRNA gene sequence similarity values between strain $\mathrm{MW} 2-25^{\mathrm{T}}$ and the type strains of all recognized species of the genus Dactylosporangium ranged from $97.6 \%$ (D. fulvum IFO $\left.14381^{\mathrm{T}}\right)$ to $99.3 \%\left(\right.$ D. aurantiacum IFO $\left.12592^{\mathrm{T}}\right)$.

The characteristics shown in Table 1 clearly indicate that strain MW2- $25^{\mathrm{T}}$ possesses some distinct phenotypic characteristics that separate it from its closest phylogenetic neighbour, D. aurantiacum NBRC $12592^{\mathrm{T}}$. In particular, peptonization of milk, minimum $\mathrm{pH}$ tolerance and utilization of D-fructose, melibiose, D-ribose, lactose and $\mathrm{L}$-arabinose are effective for the discrimination of strain MW2 $-25^{\mathrm{T}}$ from related organisms. Furthermore, low DNA-DNA relatedness values $(9.6-31.7 \%)$ were observed between strain MW2-25 $5^{\mathrm{T}}$ and the type strains of the six recognized species of the genus Dactylosporangium (see Supplementary Table S2). The DNA-DNA relatedness

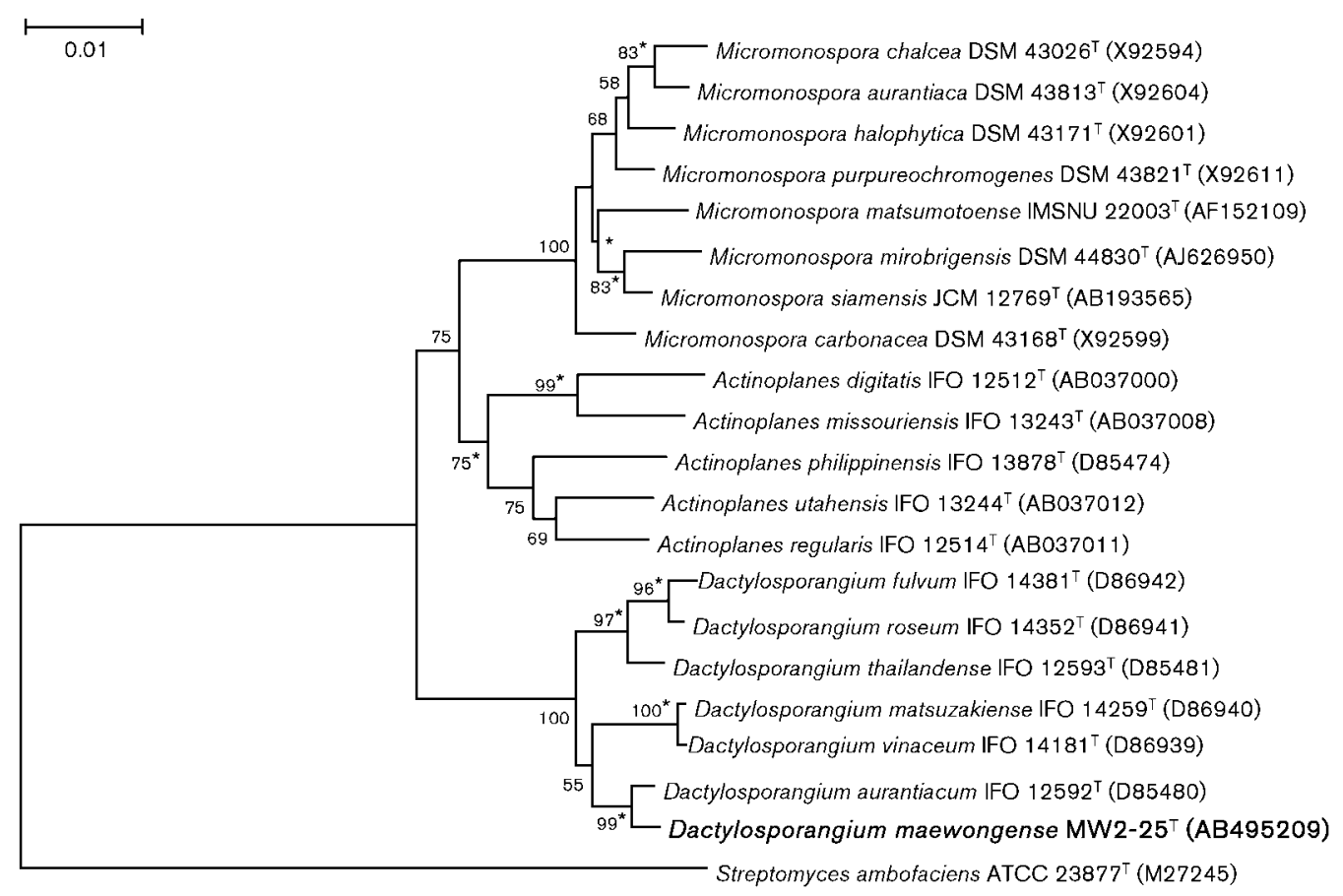

Fig. 2. Neighbour-joining tree based on almost-complete $16 \mathrm{~S}$ rRNA gene sequences showing the relationships between strain MW2-25 $5^{\top}$ and members of the genera Dactylosporangium, Micromonospora and Actinoplanes. Bootstrap values ( $\left.>50 \%\right)$ based on 1000 resamplings are shown at branch nodes. Asterisks indicate that the corresponding nodes were also found in the tree constructed using the maximum-parsimony method. Streptomyces ambofaciens ATCC $23877^{\top}$ was used as an outgroup. Bar, 0.01 substitutions per nucleotide position. 
Table 1. Differential characteristics of strain $M W 2-25^{\top}$ and the type strains of recognized species of the genus Dactylosporangium

Strains: 1, MW2-25 $;$, D. aurantiacum NBRC $12592^{\mathrm{T}}$; 3, D. thailandense NBRC $12593^{\mathrm{T}} ; 4$, D. vinaceum NBRC $14181^{\mathrm{T}}$; 5, D. matsuzakiense NBRC $14259^{\mathrm{T}}$; 6, D. roseum NBRC $14352^{\mathrm{T}}$; 7, D. fulvum NBRC $14381^{\mathrm{T}}$. All data were taken from this study. +, Positive; w, weakly positive; - , negative.

\begin{tabular}{|c|c|c|c|c|c|c|c|}
\hline Characteristic & 1 & 2 & 3 & 4 & 5 & 6 & 7 \\
\hline $\begin{array}{l}\text { Formation of globose bodies on } \mathrm{HV} \\
\text { agar }\end{array}$ & Moderate & Abundant & Abundant & Poor & Poor & Poor & Abundant \\
\hline Colour of soluble pigment on ISP 2 & None & None & $\begin{array}{l}\text { Yellowish } \\
\text { brown }\end{array}$ & Deep red & Pale yellow & None & $\begin{array}{l}\text { Yellowish } \\
\text { brown }\end{array}$ \\
\hline Reduction of nitrate & + & + & - & - & - & + & + \\
\hline Peptonization of milk & + & - & - & + & - & - & - \\
\hline Hydrolysis of starch & + & + & + & + & - & - & + \\
\hline Growth at $42{ }^{\circ} \mathrm{C}$ & $\mathrm{w}$ & $\mathrm{w}$ & - & - & - & $\mathrm{w}$ & $\mathrm{w}$ \\
\hline Maximum $\mathrm{NaCl}$ tolerance (\%) & 3 & 3 & 1.5 & 3 & 1.5 & 2 & 3 \\
\hline Minimum pH tolerance & 5 & 6 & 6 & 6 & 6 & 6.5 & 6.5 \\
\hline Glycerol & + & $\mathrm{w}$ & - & $\mathrm{w}$ & + & W & - \\
\hline Lactose & - & + & w & $\mathrm{W}$ & - & w & w \\
\hline D-Mannitol & + & $\mathrm{w}$ & $\mathrm{w}$ & + & + & - & + \\
\hline Melibiose & - & + & - & $\mathrm{W}$ & w & $\mathrm{w}$ & $\mathrm{w}$ \\
\hline Raffinose & + & $\mathrm{w}$ & + & $\mathrm{w}$ & + & - & - \\
\hline L-Rhamnose & $\mathrm{w}$ & + & w & + & $\mathrm{w}$ & - & - \\
\hline D-Ribose & $\mathrm{w}$ & - & - & $\mathrm{w}$ & - & $\mathrm{w}$ & $\mathrm{w}$ \\
\hline
\end{tabular}

value between strain MW2- $25^{\mathrm{T}}$ and $D$. aurantiacum NBRC $12592^{\mathrm{T}}$ was $31.7 \pm 0.99 \%$.

It is evident from the phenotypic and genotypic data mentioned above that strain MW2 $-25^{\mathrm{T}}$ can be distinguished from previously described species of the genus Dactylosporangium. It is, therefore, proposed that this strain be classified as representing a novel species of the genus Dactylosporangium, for which the name Dactylosporangium maewongense sp. nov. is proposed.

\section{Description of Dactylosporangium maewongense sp. nov.}

Dactylosporangium maewongense (mae.wong.en'se. N.L. neut. adj. maewongense pertaining to Maewong National Park, where the type strain was isolated).

Gram-positive, mesophilic actinomycete that forms fingershaped sporangia on short sporangiophores emerging directly from the substrate hyphae. Colonies are yellowish orange on ISP 2. Each irregular rugose sporangium contains a row of ovoid motile spores. Globose bodies are observed on modified soil extract agar and HV agar. Aerial mycelium is absent. The spore surface appears smooth. Spores are motile. No soluble pigment is produced in test culture media. Nitrate is reduced to nitrite. Utilizes cellobiose, D-mannitol, raffinose, glycerol and salicin, weakly utilizes D-galactose, D-ribose, D-xylose and Lrhamnose, but does not utilize lactose, L-arabinose, Dfructose or melibiose. Peptonization of milk, hydrolysis of starch and liquefaction of gelatin are positive, but formation of melanin and production of $\mathrm{H}_{2} \mathrm{~S}$ are negative. Optimal temperature for growth is between 25 and $30{ }^{\circ} \mathrm{C}$; no growth occurs above $42{ }^{\circ} \mathrm{C}$. The maximum $\mathrm{NaCl}$ concentration for growth is $3 \%(\mathrm{w} / \mathrm{v})$. Cell wall contains glutamic acid, glycine, alanine, meso- $\mathrm{A}_{2} \mathrm{pm}$ and $3-\mathrm{OH}-$ meso- $\mathrm{A}_{2} \mathrm{pm}$. The acyl type of the cell wall is the glycolyl type. The predominant menaquinone is $\mathrm{MK}-9\left(\mathrm{H}_{8}\right)$. The characteristic whole-cell sugars are glucose, xylose, rhamnose, ribose and trace amounts of arabinose. The phospholipid profile contains diphosphatidylglycerol, phosphatidylglycerol, lysyl phosphatidylglycerol and phosphatidylethanolamine, but not phosphatidylcholine. The major cellular fatty acids of the type strain are iso- $\mathrm{C}_{16: 0}$, iso- $\mathrm{C}_{15: 0}$, anteiso- $\mathrm{C}_{15: 0}$, iso- $\mathrm{C}_{14: 0}$, anteiso- $\mathrm{C}_{17: 0}$, iso$\mathrm{C}_{17: 0}, \mathrm{C}_{18: 0}, \mathrm{C}_{16: 0}, \mathrm{C}_{17: 0}$, cis-9- $\mathrm{C}_{18: 1}$, anteiso- $\mathrm{C}_{17: 1}$, cis9- $\mathrm{C}_{17: 1}$ and 10-methyl- $\mathrm{C}_{17: 0}$.

The type strain, MW2-25 ${ }^{\mathrm{T}}\left(=\mathrm{BCC} 34832^{\mathrm{T}}=\mathrm{JCM} 15933^{\mathrm{T}}\right)$, was isolated from a soil sample collected from Maewong National Park in Nakhon Sawan Province, Thailand. The DNA G + C content of the type strain is $73.2 \mathrm{~mol} \%$. 


\section{Acknowledgements}

We are grateful to BIOTEC Culture Collection, BIOTEC Central Research Unit, National Center for Genetic Engineering and Biotechnology and National Science and Technology Development Agency (NSTDA) for supporting this project. We also thank the Biological Resource Center, National Institute of Technology and Evaluation, Kisarazu, Chiba, Japan, for supplying cultures of reference strains. This study was supported in part by Department of Applied Biology, Faculty of Science, King Mongkut's Institute of Technology, Ladkrabang, Bangkok, Thailand.

\section{References}

Arai, T. (1975). Culture Media for Actinomycetes. Tokyo: The Society for Actinomycetes Japan.

Chun, J., Lee, J.-H., Jung, Y., Kim, M., Kim, S., Kim, B. K. \& Lim, Y.-W. (2007). EzTaxon: a web-based tool for the identification of prokaryotes based on 16S ribosomal RNA gene sequences. Int J Syst Evol Microbiol 57, 2259-2261.

Collins, M. D., Pirouz, T., Goodfellow, M. \& Minnikin, D. E. (1977). Distribution of menaquinones in actinomycetes and corynebacteria. $J$ Gen Microbiol 100, 221-230.

Ezaki, T., Hashimoto, Y. \& Yabuuchi, E. (1989). Fluorometric deoxyribonucleic acid-deoxyribonucleic acid hybridization in microdilution wells as an alternative to membrane filter hybridization in which radioisotopes are used to determine genetic relatedness among bacterial strains. Int J Syst Bacteriol 39, 224-229.

Felsenstein, J. (1985). Confidence limits on phylogenies: an approach using the bootstrap. Evolution 39, 783-791.

Gordon, R. E., Barnett, D. A., Handerhan, J. E. \& Pang, C. H.-N. (1974). Nocardia coeliaca, Nocardia autotrophica, and the nocardin strain. Int J Syst Bacteriol 24, 54-63.

Hamaki, T., Suzuki, M., Fudou, R., Jojima, Y., Kajiura, T., Tabuchi, A., Sen, K. \& Shibai, H. (2005). Isolation of novel bacteria and actinomycetes using soil-extract agar medium. J Biosci Bioeng 99, 485-492.

Hayakawa, M., Sadakata, T., Kajiura, T. \& Nonomura, H. (1991). New methods for the highly selective isolation of Micromonospora and Microbispora from soil. J Ferment Bioeng 72, 320-326.

Itoh, T., Kudo, T., Parenti, F. \& Seino, A. (1989). Amended description of the genus Kineosporia, based on chemotaxonomic and morphological studies. Int J Syst Bacteriol 39, 168-173.

Kämpfer, P. \& Kroppenstedt, R. M. (1996). Numerical analysis of fatty acid patterns of coryneform bacteria and related taxa. Can J Microbiol 42, 989-1005.

Kawamoto, I., Oka, T. \& Nara, T. (1981). Cell wall composition of Micromonospora olivoasterospora, Micromonospora sagamiensis, and related organisms. J Bacteriol 146, 527-534.

Kluge, A. G. \& Farris, J. S. (1969). Quantitative phyletics and the evolution of anurans. Syst Zool 18, 1-32.

Koch, C., Kroppenstedt, R. M., Rainey, F. A. \& Stackebrandt, E. (1996). 16S ribosomal DNA analysis of the genera Micromonospora, Actinoplanes, Catellatospora, Catenuloplanes, Couchioplanes, Dactylosporangium, and Pilimelia and emendation of the family Micromonosporaceae. Int J Syst Bacteriol 46, 765-768.

Komagata, K. \& Suzuki, K. (1987). Lipid and cell-wall analysis in bacterial systematics. Methods Microbiol 19, 161-207.

Kroppenstedt, R. M. (1985). Fatty acid and menaquinone analysis of actinomycetes and related organisms. In Chemical Methods in Bacterial Systematics (Society for Applied Bacteriology Technical
Series vol. 20), pp. 173-199. Edited by M. Goodfellow \& D. E. Minnikin. New York: Academic Press.

Kumar, S., Tamura, K., Jakobsen, I. B. \& Nei, M. (2001). MEGA2: Molecular evolutionary genetics analysis software. Bioinformatics 17, 1244-1245.

Lechevalier, M. P. \& Lechevalier, H. A. (1970). Chemical composition as a criterion in the classification of aerobic actinomycetes. Int $J$ Syst Bacteriol 20, 435-443.

Lechevalier, M. P. \& Lechevalier, H. A. (1980). The chemotaxonomy of actinomycetes. In Actinomycete Taxonomy, pp. 227-291. Edited by A. Dietz \& D. W. Thayer. Arlington, VA: Society for Industrial Microbiology.

Lechevalier, M. P., De Bièvre, C. \& Lechevalier, H. A. (1977). Chemotaxonomy of aerobic actinomycetes: phospholipid composition. Biochem Syst Ecol 5, 249-260.

Minnikin, D. E., Alshamaony, L. \& Goodfellow, M. (1975). Differentiation of Mycobacterium, Nocardia, and related taxa by thin-layer chromatographic analysis of whole-organism methanolysates. J Gen Microbiol 88, 200-204.

Minnikin, D. E., O’Donnell, A. G., Goodfellow, M., Alderson, G., Athalye, M., Schaal, A. \& Parlett, J. H. (1984). An integrated procedure for the extraction of bacterial isoprenoid quinones and polar lipids. J Microbiol Methods 2, 233-241.

Saitou, N. \& Nei, M. (1987). The neighbor-joining method: a new method for reconstructing phylogenetic trees. Mol Biol Evol 4, 406425.

Sasser, M. (1990). Identification of bacteria by gas chromatography of cellular fatty acids, MIDI Technical Note 101. Newark, DE: MIDI Inc.

Shirling, E. B. \& Gottlieb, D. (1966). Methods for characterization of Streptomyces species. Int J Syst Bacteriol 16, 313-340.

Shomura, T., Kojima, M., Yoshida, J., Ito, M., Amano, S., Totsugawa, K., Niwa, T., Inouye, S., Ito, T. \& Niida, T. (1980). Studies on a new aminoglycoside antibiotic, dactimicin. I. Producing organism and fermentation. J Antibiot 33, 924-930.

Shomura, T., Yoshida, J., Miyadoh, S., Ito, T. \& Niida, T. (1983). Dactylosporangium vinaceum sp. nov. Int J Syst Bacteriol 33, 309313.

Shomura, T., Amano, S., Tohyama, H., Yoshida, J., Ito, T. \& Niida, T. (1985). Dactylosporangium roseum sp. nov. Int J Syst Bacteriol 35, 14.

Shomura, T., Amano, S., Yoshida, J. \& Kojima, M. (1986). Dactylosporangium fulvum sp. nov. Int J Syst Bacteriol 36, 166-169.

Stackebrandt, E., Rainey, F. A. \& Ward-Rainey, N. L. (1997). Proposal for a new hierarchic classification system, Actinobacteria classis nov. Int J Syst Bacteriol 47, 479-491.

Staneck, J. L. \& Roberts, G. D. (1974). Simplified approach to identification of aerobic actinomycetes by thin-layer chromatography. Appl Microbiol 28, 226-231.

Suriyachadkun, C., Chunhametha, S., Thawai, C., Tamura, T., Potacharoen, W., Kirtikara, K. \& Sanglier, J. J. (2009). Planotetraspora thailandica sp. nov., isolated from soil in Thailand. Int J Syst Evol Microbiol 59, 992-997.

Tamaoka, J. (1994). Determination of DNA base composition. In Chemical Methods in Prokaryotic Systematics, pp. 463-470. Edited by M. Goodfellow \& A. G. O'Donnell. Chichester: Wiley.

Tamaoka, J. \& Komagata, K. (1984). Determination of DNA base composition by reversed-phase high-performance liquid chromatography. FEMS Microbiol Lett 25, 125-128.

Thiemann, J. E. (1970). Dactylosporangium thailandensis should be D. thailandense. Int J Syst Bacteriol 20, 59. 
Thiemann, J. E., Pagani, H. \& Beretta, G. (1967). A new genus of the Actinoplanaceae: Dactylosporangium, gen. nov. Arch Mikrobiol 58, 4252.

Thompson, J. D., Higgins, D. G. \& Gibson, T. J. (1994). CLUSTAL $\mathrm{W}$ : improving the sensitivity of progressive multiple sequence alignment through sequence weighting, position specific gap penalties and weight matrix choice. Nucleic Acids Res 22, 46734680.
Uchida, K. \& Aida, K. (1984). An improved method for the glycolate test for simple identification of acyl type of bacterial cell walls. J Gen Appl Microbiol 30, 131-134.

Verlander, C. P. (1992). Detection of horseradish peroxidase by colorimetry. In Nonisotopic DNA Probe Techniques, pp. 185-201. Edited by L. J. Kricka. New York: Academic Press.

Williams, S. T. \& Cross, T. (1971). Actinomycetes. Methods Microbiol 4, 295-334. 